\title{
Morphology of the Interstitial Tissue of Active and Resting Testis of the Guinea Fowl
}

\author{
Morfología del Tejido Intersticial del Testículo Activo y en Reposo de la Gallina de Guinea
}

Palanisamy Dharani'; S. Usha Kumary'; Venkatesan Sundaram²; Cecilia Joseph ${ }^{1}$ \& Geetha Ramesh ${ }^{1}$

DHARANI, P.; KUMARY, S. U.; SUNDARAM, V.; JOSEPH, C. \& RAMESH, G. Morphology of the interstitial tissue of active and resting testis of the Guinea fowl. Int. J. Morphol., 35(4):1359-1362, 2017.

SUMMARY: The morphology of the interstitial tissue of sexually active and resting testis of the guinea fowl were studied. Six adult health birds of active and resting phases of reproductive cycle were used for this study. The interstitial tissue consisted of loose connective tissue, interstitial cells (Leydig cells), few connective cells, blood vessels and adrenergic nerve fibres in the present study in both active and resting testes. The interstitial tissue was compact in sexually active testis whereas, the volume of the tissue was found to be increased in resting testis. The loose connective tissue of the interstitial tissue composed of mainly of collagen fibres and few reticular fibres whereas elastic fibres were absent in both groups studied. The interstitial cells appeared in clusters of a few cells and were relatively less in the active testis than the resting testis. The interstitial cells were pale staining or polygonal cells with euchromatic nuclei with few large lipid droplets in the active testis whereas the cells were flat and highly heterochromatic with numerous small lipid droplets in resting testis. Few macrophages were found only in resting testis. Interstitial cells showed negative reaction to alkaline, acid phosphatases and PAS in both groups studied but positive for lipids. The interstitial tissue was well vascularised with centrally located blood vessels in the active testis whereas the blood vessels were small and inconspicuous in the resting testis. The lymphatic vessels were not identified in both groups studied.

KEY WORDS: Morphology; Interstitial tissue; Active; Resting; Testis; Guinea fowl.

\section{INTRODUCTION}

Reproduction in birds is a cyclic phenomenon and mainly depends on the photoperiod, rainfall, humidity, temperature and food availability (Lake, 1981). The guinea fowl is a long day seasonal breeder and exhibits peak breeding activity during summer and no breeding activity takes place during winter (Ali et al., 2015; Shil et al., 2015).The changes in the breeding activity is reflected in the internal morphology of the testis. The study of morphological features during different phases of reproductive cycle can lead to better understanding of the seasonality of reproduction in these birds.

The interstitial tissue of the testis plays a major role in the function of the testis viz., mechanical support to the seminiferous tubules and blood vessels, production of testosterone by interstitial cells (Leydig cells), participation in the sustentacular cell barrier and regulation of the sustentacular cell (Sertoli cell) functions. Several studies were done on the testis of several avian species (Barker \& Kendall, 1984) with brief description about the interstitial cells. Very few exclusive studies on the interstitial tissue have been done on the avian species (Rothwell \& Tingari, 1973; Rothwell, 1975; Aire, 1997) but detailed morphology of the interstitial tissue of the guinea fowl during active and resting phases of the reproductive cycle is still lacking.

The present study is aimed to provide the detailed knowledge on the morphological variations of the interstitial tissue of the Guinea fowl testis during active and resting phases of the reproductive cycle which helps to understand the biology of the testis and seasonality of reproduction in the guinea fowl.

\section{MATERIAL AND METHOD}

A total of 12 healthy breeding guinea cocks $(n=6)$ with 1.3 to $1.4 \mathrm{~kg}$ average body weight were collected from the Poultry Research Station, Tamil Nadu Veterinary and 
Animal Sciences University, Chennai, India during active (i.e. peak summer month of May) and resting phases (i.e. during winter month of December) of reproductive cycle. The present study was approved by the institutional ethical committee. The birds were euthanized by cervical dislocation and the testes were collected. The testes were fixed in Neutral Buffered Formalin, Bouin's fluid and modified Davidson's fixative. The tissue samples were processed as per the standard procedures of paraffin embedding (Spencer $\&$ Bancroft, 2013). Tissue sections of 5-8 $\mu \mathrm{m}$ thickness were cut and utilized for utilized for various histological and histochemical staining methods like Haematoxylin Eosin (H\&E) method, Masson's trichrome method, Verhoeff's Elastic stain, Periodic Acid-Schiff reaction for neutral mucopolysaccharides, Sudan Black B for fats (Singh \& Sulochana, 1996) and Gomori's method for reticular fibres (Spencer \& Bancroft). Fresh, unfixed cryosections were utilized for histochemical staining methods Gomori's alkaline phosphatase cobalt method and Gomori's method for acid phosphatase (Singh \& Sulochana).

\section{RESULTS AND DISCUSSION}

The interstitial tissue was found in the spaces between the adjacent seminiferous tubules. It consisted of loose connective tissue, interstitial cells, few connective cells, blood vessels and adrenergic nerve fibres in the present study in both active and resting testes (Figs. $1 \& 2$ ). There is little or no variation observed in the organisation of interstitial tissue of the guinea fowl from the domestic fowl (GonzálezMorán \& Soria-Castro, 2010).

The interstitial tissue was very compact, either triangular or quadrilateral in shape (Fig. 1) in the sexually active birds whereas the volume of the interstitial tissue was increased and occupied greater proportion of the testis in sexually resting birds (Fig. 2) which is similar to the reports of Gofur et al. (2008) in ostriches and Islam et al. (2009) in jungle crow. There is no clear demarcation between the interstitial tissue and the peritubular tissue in the sexually active birds due to the compactness whereas the demarcation was relatively clear in resting testis due to the physiological atrophy seminiferous tubules in the present study which is similar to the findings of Rothwell \& Tingari in domestic fowl.

The connective tissue of the interstitium composed of mainly of collagen fibres, few reticular fibres in both groups studied. However, the collagen fibres were not observed close to the peritubular tissue which is similar to the findings of Aire in birds. The elastic fibres were not noticed in the present study in both the groups studied.
The interstitial cells appeared in clusters made up of only a few cells in the interstitial tissue, especially at the angles and rarely found at places where the seminiferous tubules lie and run parallel to each other in both active and resting testes. The number of interstitial cells were relatively less in the active testis when compare with the resting testis. The shape of the interstitial cells was highly variable and ranged from round, oval, polyhedral, triangular and flattened. Similarly, the shape of the nucleus also varied from round to flat. The position of nucleus was either central or eccentric. The interstitial cells of the sexually active testis were pale staining, predominantly oval or polygonal cells with euchromatic nuclei and few large lipid droplets (Fig.1) which is similar to reports in drakes and domestic fowl (Aire). The interstitial cells were numerous in the resting testis with foamy appearance. The nuclei were heterochromatic with numerous small lipid droplets (Fig. 2). Two types of interstitial cells were identified by Aire based on the electron density and mitochondrial characteristics in the resting testis in birds, which could not be identified in the present study.

Kremer \& Budras (1988) in Pekin drake stated that the other cell population in the interstitial tissue apart from the interstitial cells were few fibroblasts, reticular cells, macrophages, plasma cells, lymphocytes and formed elements of the blood. The mast cells and plasma cells were not observed in both groups of testes in the present study. However, the presence of mast cells is considered as very important for normal spermatogenesis in man (Meineke et al., 2000). Few fibroblasts were found in both groups. Macrophages may represent as much as $25 \%$ of the interstitial cell population in adult mice and rats (Hutson, 1992). But the macrophages were not noticed in sexually active testis, however few macrophages were found in sexually resting testis between blood vessels and Interstitial cells (Fig. 2). The presence of macrophages found in the sexually resting testis can be attributed to the removal of the disintegrated interstitial cells during non-breeding season in birds. In the present study, the Interstitial cells showed negative reaction to alkaline, acid phosphatases and PAS in both groups studied. But, Interstitial cells are said to be positive for alkaline phosphatase in turkey (Bakst et al., 2007). The interstitial cells were highly positive for lipids (Fig. 3) in both groups without much difference as indicated by Islam et al. in jungle crow and Bakst et al. in turkey.

The interstitial tissue was well vascularised and the blood vessels mostly were located at centre in the sexually active testis (Fig. 4) whereas the blood vessels were small and inconspicuous in the sexually resting testis as reported in jungle crow (Islam et al., 2015).

Aire stated that the lymph drainage of the interstitial 


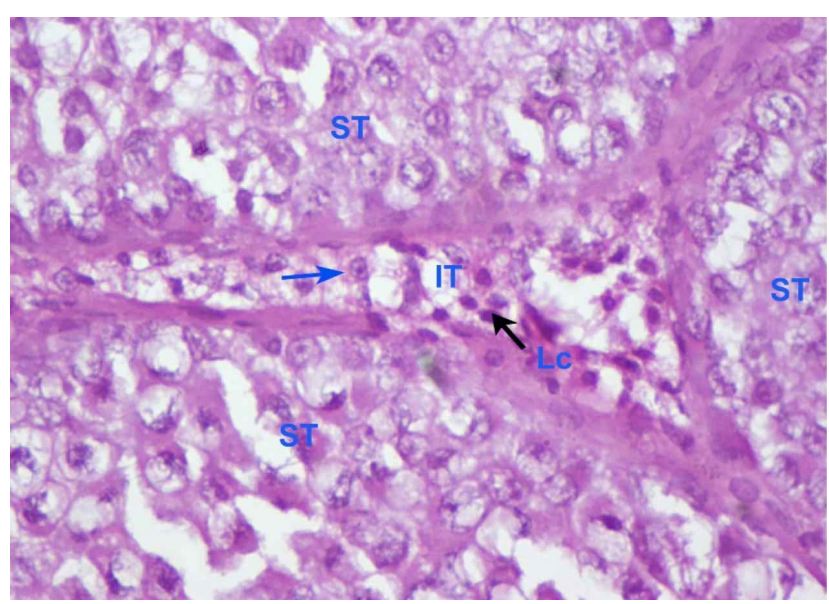

Fig. 1. The interstitial tissue of the sexually active Guinea fowl testis. H\&E 400x. ST- Seminiferous tubule; IT-Interstitial tissue; Lc- Interstitial cells

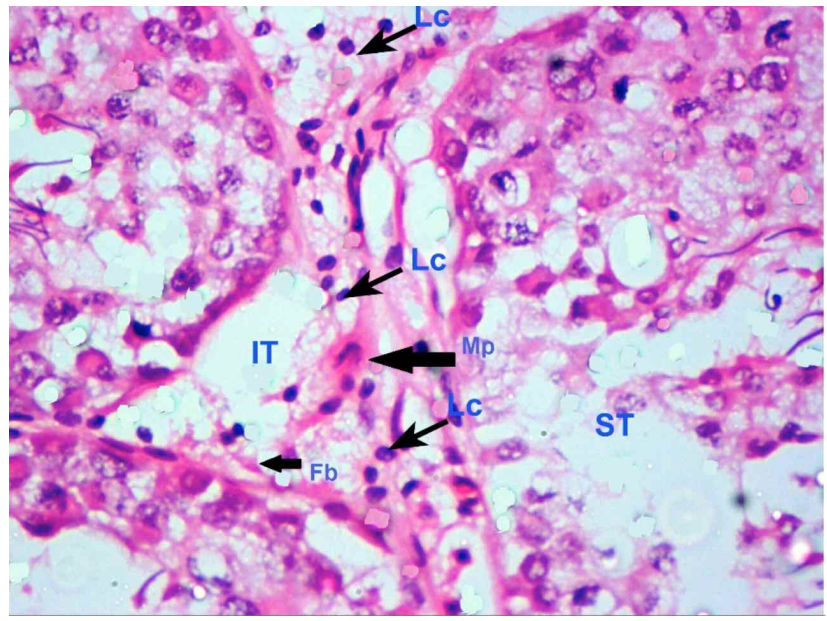

Fig. 2. The interstitial tissue of the sexually resting Guinea fowl testis. H\&E 400x. ST- Seminiferous tubule; IT-Interstitial tissue; Lc- Interstitial cells; Fb-fibroblast; Mp-Macrophage.

tissue of birds was by means of sparse lymphatic vessels which are generally interposed between the Interstitial cells, blood vessels and peritubular myofibroblast tissue. But the lymphatic vessels were poorly developed and could not be identified in both active and resting testis in the present study which is in concurrence with the statement of Madekurozwa (2013) in birds. The inability of identifying the lymphatic vessels under light microscope may be due to the presence of few and poorly developed lymphatics in birds as opined by Aire. The nerve filaments were also noticed in the interstitium of testis of guinea fowl in both age groups.

DHARANI, P.; KUMARY, S. U.; SUNDARAM, V.; JOSEPH, C. \& RAMESH, G. Morfología del tejido intersticial del testículo activo y en reposo de la gallina de Guinea. Int. J. Morphol., 35(4):1359-1362, 2017.

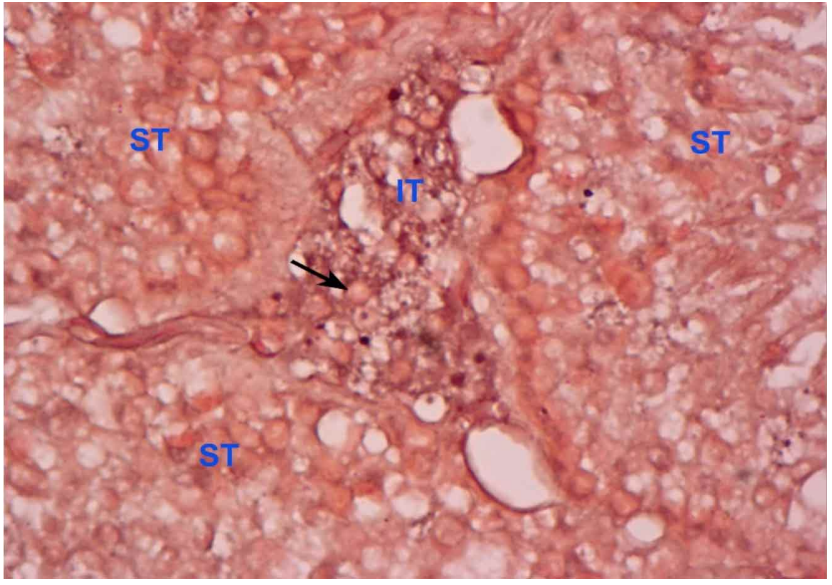

Fig. 3. The interstitial tissue of the sexually active Guinea fowl testis showing the Sudan black B positive cytoplasm (black colour). Sudan black B 400x.

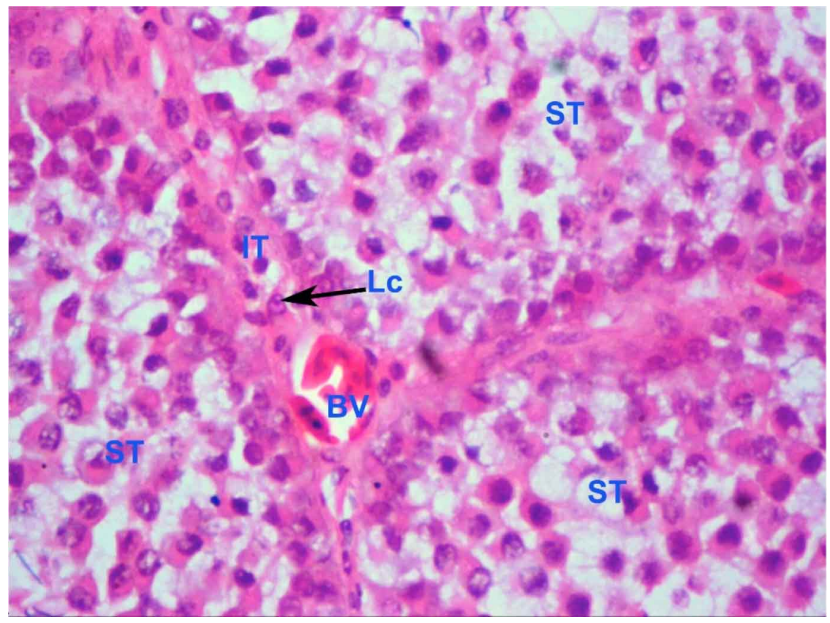

Fig. 4. The interstitial tissue of the sexually active Guinea fowl testis. H\&E 400x. ST- Seminiferous tubule; IT-Interstitial tissue; Lc- Interstitial cells; BV-Blood vessel.

RESUMEN: Se estudió la morfología del tejido conectivo intersticial en testículos sexualmente activos y en reposo de la gallina de Guinea (Numida meleagris). Se utilizaron seis gallinas de Guinea machos adultos sanos, en fase activa y de reposo del ciclo reproductivo. El tejido conectivo intersticial estaba formado por tejido conectivo laxo, células endocrinas intersticiales, pocas células conectivas, vasos sanguíneos y fibras nerviosas adrenérgicas, tanto en testículos activos como en reposo. El espacio intertubular en los testículos sexualmente activos era menor en comparación a los del testículos en reposo. El tejido conectivo laxo estaba compuesto principalmente de fibras colágenas y en menor cantidad de fibras reticulares. Las fibras elásticas estaban ausentes en ambos grupos. Las células endocrinas intersticiales se organizaban en racimos de pocas células y se observaban con menor frecuencia en los testículos sexualmente activos. Las células endocrinas intersticiales de los testículos activos presentaban forma poligonal, citoplasma levemente eosinofílico con algunas gotas lipídicas de gran tamaño en su interior y nucleos redondos con cromatina laxa. 
Las células intersticiales de los testículos en reposo eran planas y altamente heterocromáticas, con numerosas gotas lipídicas pequeñas en su citoplasma. Las células intersticiales mostraron una reacción negativa a las fosfatasas ácidas, alcalinas y PAS en ambos grupos, Sin embargo presentaron reacción positivas para los lípidos. El tejido conectivo intersticial estaba bien vascularizado con vasos sanguíneos situados centralmente en el testículo activo y vasos sanguíneos pequeños y discretos en el testículo en reposo. Los vasos linfáticos no fueron identificados en los dos grupos estudiados.Los macrófagos fueron observados solo en los testículos en reposo, aunque en escasa cantidad.

PALABRAS CLAVE: Morfología; Tejido intersticial; Activo; En reposo; Testículo; Gallina de Guinea.

\section{REFERENCES}

Aire, T. A. The structure of the interstitial tissue of the active and resting avian testis. Onderstepoort J. Vet. Res., 64(4):291-9, 1997.

Ali, M. Z.; Qureshi, A. S.; Rehan, S.; Akbar, S. Z. \& Manzoor, A. Seasonal variations in histomorphology of testes and bursa, immune parameters and serum testosterone concentration in male guinea fowl (Numida meleagris). Pak. Vet. J., 35(1):88-92, 2015.

Bakst, M. R.; Akuffo, V.; Trefil, P. \& Brillard, J. P. Morphological and histochemical characterization of the seminiferous epithelial and Leydig cells of the turkey. Anim. Reprod. Sci., 97(3-4):303-13, 2007.

Barker, S. G. \& Kendall, M. D. A study of the rete testis epithelium in several wild birds. J. Anat., 138(Pt. 1):139-52, 1984.

Gofur, M. R.; Khan, M. Z. I.; Karim, M. R. \& Islam, M. N. Histomorphology and histochemistry of testis of indigenous bull (Bos indicus) of Bangladesh. Bangladesh J. Vet. Med., 6(1):67-74, 2008.

González-Morán, M. G. \& Soria-Castro, E. Changes in the tubular compartment of the testis of Gallus domesticus during development. Br. Poult. Sci., 51(2):296-307, 2010.

Hutson, J. C. Development of cytoplasmic digitations between Leydig cells and testicular macrophages of the rat. Cell Tissue Res., 267(2):385-9, 1992.

Islam, M. N.; Aoyama, M \& Sugita, S. Seasonal cycle of leydig cells in the Japanese Jungle Crow (Corvus macrorhynchos). Asian J. Med. Biol. Res., 1(1):65-73, 2015.

Islam, M. N.; Zhu, X. B.; Aoyama, M. \& Sugita, S. Histological and morphometric analyses of seasonal testicular variations in the Jungle Crow (Corvus macrorhynchos). Anat. Sci. Int., 85(3):121-9, 2009.

Kremer, A. \& Budras, K. D. Lymph system and lymphatic drainage in the testis of pekin drake. Anat. Histol. Embryol., 17(3):246-57, 1988.

Lake, P. E. Male Genital Organs. In: Kim, A. S. \& Lellard, M. C. (Eds.). Form and Function in Birds. London, Academic Press, 1981.

Madekurozwa, M. C. Post-hatch changes in the immunoexpression of desmin, smooth muscle actin and vimentin in the testicular capsule and interstitial tissue of the japanese quail (Coturnix coturnix japonica). Anat. Histol. Embryol., 42(5):369-78, 2013.

Meineke, V.; Frungieri, M. B.; Jessberger, B.; Vogt, H. \& Mayerhofer, A. Human testicular mast cells contain tryptase: increased mast cell number and altered distribution in the testes of infertile men. Fertil. Steril., 74(2):239-44, 2000

Rothwell, B. \& Tingari, M. D. The ultrastructure of the boundary tissue of the seminiferous tubule in the testis of the domestic fowl (Gallus domesticus). J. Anat., 114(Pt. 3):321-8, 1973.

Rothwell, B. Designation of the cellular component of the peritubular boundary tissue of the seminiferous tubule in the testis of the fowl (Gallus domesticus). Br. Poult. Sci., 16(5):527-9, 1975.
Shil, S. K.; Quasem, M. A. \& Rahman, M. L. Histological and morphometric analysis of testes of Adult quail (Coturnix coturnix japonica) of Bangladesh. Int. J. Morphol., 33(1):100-4, 2015.

Singh, U. B. \& Sulochana, S. Handbook of Histological and Histochemical Techniques. $2^{\text {nd }}$ ed. Hyderabad, Premier Publishing House, 1997.

Spencer, L. T. \& Bancroft, J. D. Tissue Processing. In: Kim Suvarna, S.; Layton, C. \& Bancroft, J. D. (Eds). Bancroft's Theory and Practice of Histological Techniques. $7^{\text {th }}$ ed. London, Churchill Livingstone, 2013.

\author{
Corresponding author: \\ Dr. Venkatesan Sundaram \\ Department of Basic Veterinary Sciences \\ Faculty of Medical Sciences \\ The University of The West Indies \\ St. Augustine, Trinidad \\ TRINIDAD AND TOBAGO
}

Email: mailto:drvenkat1971@gmail.com

Received: 21-06-2017

Accepted: 06-09-2017 